\title{
Statistical Investigation of Determining Factors of Rural Households' Income: Evidence from South Eastern Ethiopia
}

Mekonin Abera Negeri (Corresponding author)

Department of Statistics, College of Natural and Computational Science, Madda Walabu University

PO Box 247, Bale-Robe, Ethiopia

E-mail: tgmoke@gmail.com

Dereje Bekele Dessie

Department of Statistics, College of Natural and Computational Science, Madda Walabu University

PO Box 247, Bale-Robe, Ethiopia

E-mail: dereje1999@gmail.com

Received: April 25, $2018 \quad$ Accepted: May 3, 2018

doi:10.5296/jas.v6i2.13225 URL: https://doi.org/10.5296/jas.v6i2.13225

\begin{abstract}
This study pinpointed determining factors of rural households' income with reference to Sinana district, South Eastern Ethiopia using Micro econometric analysis. To conduct this investigation, household level data is gathered from 267 randomly selected rural household heads from four kebeles of the district. Descriptive statistics and econometric model were used for the analysis of primary data. The result of descriptive statistics showed that $71.5 \%$ of the sampled household heads were involved in farming occupation category whereas the rest $12 \%$ and $16.5 \%$ were involved in government job and trading occupation categories, respectively. The result confirmed that farming occupation category is the prominent source of income for the rural households in the study district. The result of classical linear regression depicted that age of household head, land holding size, annual expenditure and total livestock holding were significant determining factors of annual total income. Square root transformation was made on annual income to decrease the variance and the result
\end{abstract}


further revealed that square root of annual total income increases with the increase in land holding size, annual expenditure and total livestock holding whereas decreases with the increase in age of household head. In order to accelerate the diversification of the annual income of rural communities, those significant variables could get special focus by policy makers and development agents.

Keywords: Income, Rural households, Sinana district, Multiple linear regression

\section{Introduction}

Nowadays, the agricultural strategy will direct on placing major effort to support the intensification of marketable farm products, both for domestic and export markets. These strategies have been implemented both by small and large scale farmers. The shift to produce high value crops, a special focus on high potential areas, facilitating the commercialization of agriculture, supporting the development of large scale commercial agriculture are among the fundamental strategies to be set both in developing and developed countries to improve the livelihood of rural households. The feasibility of these strategies will continue to be the major source of agricultural growth especially for smallholder farming. To complement this, concerted support will be given to increase private investment in large commercial farms.

The high contribution of the agricultural sector to Gross Domestic Product (GDP) underlines the limited diversification of most African economies. On average, agriculture contributes 15 percent of total GDP; however it ranges from below 3 percent in Botswana and South Africa to more than 50 percent in Chad, implying a diverse range of economic structures. This implies that agriculture employs more than half of the total labor force (International Monetary Fund, 2012). However, Ethiopian agriculture is characterized by low productivity. Over the last two decades, it has not been able to produce sufficient food to feed the country's rapidly growing population. Rural households in many different contexts have been found to diversify their income sources, allowing them to spread risk and smooth consumption over the year (Awoniyi and Salman, 2008).

In Ethiopia, the agricultural sector depicted a moderate growth rate of 6.4 percent mainly due to 7.2 percent increase in crop production in general and 7.5 percent expansion in grain crop production in 2014/2015. The total grain production reached 270.4 million quintals, of which cereal production accounted for 87.3 percent while pulses and oil seeds comprised 12.7 percent. Cereals and oilseeds production went up by 9.4 and 6.9 percent over the preceding year owing to the 3 and 4.9 percent expansion in cultivated land area, respectively (National Bank of Ethiopia, 2014/2015). There are several factors that determine rural households' potential to diversify their livelihood strategies away from crop and livestock production into off-farm or non-farm economic activities. A substantial and increasing share of off-farm or non-farm income in total income among rural households of many developing countries has been reported by different studies (Haggblade et al., 2007).

Empirical study has revealed that non-farm sources contribute to 40-50 percent to average rural household incomes across developing world (World Bank, 2008). According to Amare and Belaineh (2013), household heads with formal education were found to have better 
information and knowledge to participate in different activities and to earn better income. Bekelu and Abdi-Khali (2013) indicated that those farmers who have got intensive contact with extension workers tend to diversify their income. Yishak (2016) argued that agricultural sector alone cannot be relied upon as the main activity for rural households as a means of improving livelihood, achieving food security and reducing poverty so that income diversification is gaining prominent in rural households' income and food security.

In the study of assessing determinant factors of income diversification, Yishake and Abebe (2015) identified that years of schooling of household head is the most important factor that encourages farm households' decision to engage into off-farm activities. They further confirmed that factors such as farm size, membership in farmers' cooperatives and distance from market center were the most influential factors that negatively enforced households to participate in non-farm activity to earn income. Mekonin (2017) found that age of household head, livestock holding in TLU, access to improved coffee seed, access to credit and total land size owned by the household had significant relationship with the log of annual total income. Another study by Aikaili (2010) explained that education of household head, farm size and ownership of non-farm rural enterprise as important factors determining the income of rural households.

The motivation of the current investigation is that assessing determinant factors of rural households' income is being a serious issue in developing countries; there is study gap in the study site regarding the diversification of income which can improve the livelihood strategies of the rural households. Therefore, it is deemed crucial to undertake household level study to pinpoint different factors influencing annual income of rural communities involved in different occupation categories with reference to Sinana district, South Eastern, Ethioia. This investigation would have indispensable role in poverty reduction and for improvement of the livelihood in the study area. With this brief introduction, the rest of the paper is structured as follows. The next section introduces statistical data and methodology, the third section deals with results and discussion and the last section presents concluding remarks and recommendations.

\section{Methodology}

The study was conducted in Sinana district of Bale zone which is located in South Eastern part of Ethiopia. Bale zone is known by agricultural activities such as crop production and animal production. In order to gather necessary information for the current investigation, a two stage random sampling technique was used to select a representative sample from the district. At the first stage, four kebeles out of twenty rural kebeles of the district were selected by simple random sampling technique. At the second stage, 267 households were selected by systematic random sampling for interview. The sample size was calculated using the simplified sample size determination formula for proportions (Cochran, 1977). Structured questionnaire was used to generate primary data from the selected households. For the analysis data, SPSS version 20 is used. Both descriptive statistics and Econometric model were applied for the analysis of the primary data. Descriptive statistics such as mean, percentages and standard deviation were used wherever necessary. An econometric model, a 


\section{Al Macrothink}

Journal of Agricultural Studies

ISSN 2166-0379

2018, Vol. 6, No. 2

classical linear regression, is selected to identify the major socioeconomic and demographic determinants of rural households' income. Multiple linear regression is a type of regression model which is used to describe and evaluate the relationship between continuous dependent variable y and a set of two or more explanatory variables. This model is selected for its practical applicability and its econometric specification in matrix form is given as:

$\boldsymbol{y}=\boldsymbol{X}^{\prime} \boldsymbol{\beta}+\boldsymbol{U}$

1

$y=\left[\begin{array}{c}y_{1} \\ y_{2} \\ \vdots \\ y_{n}\end{array}\right]_{(n \times 1)}, X=\left[\begin{array}{ccccc}1 & x_{11} & x_{21} & \cdots & x_{k 1} \\ 1 & x_{12} & x_{22} & \cdots & x_{k 2} \\ \vdots & \vdots & \vdots & \vdots & \vdots \\ 1 & x_{1 n} & x_{2 n} & \cdots & x_{k n}\end{array}\right]_{n \times(k+1)} \quad, \beta=\left[\begin{array}{c}\beta_{0} \\ \beta_{1} \\ \vdots \\ \beta_{k}\end{array}\right]_{(k+1) \times 1} \quad$ and $U=\left[\begin{array}{c}u_{1} \\ u_{2} \\ \vdots \\ u_{n}\end{array}\right]_{(n \times 1)}$

Where, $\mathrm{y}$ is vector of observations on the explained variable, $\mathrm{X}$ is $\mathrm{nx}(\mathrm{k}+1)$ matrix of observations on the explanatory variables and the first column of 1's represents the intercept term, $\mathrm{U}$ is an $\mathrm{nx} 1$ column vector of errors, $\beta$ is $(\mathrm{k}+1) \mathrm{x} 1$ column vector of parameters to be estimated. The dependent variable for this study was annual total income and the square root transformation was made to reduce the variance among the income of households. The specific econometric model and variables used in the current study were as follows.

$y=\beta_{0}+\beta_{1} x_{1}+\beta_{2} x_{2}+\cdots+\beta_{10} x_{10}+u$

On the basis of the reviewed literatures, ten explanatory variables which are supposed to influence the annual total income of rural households are selected. These variables are presented in the Table below with their measurement and hypothesized or expected sign on the dependent variable.

Table 1: Variable selection and hypothesis

\begin{tabular}{|c|c|}
\hline Variables of the study & Expected Sign \\
\hline \multicolumn{2}{|l|}{ Dependent Variable } \\
\hline Annual total income (Ethiopian Birr) & \\
\hline \multicolumn{2}{|l|}{ Independent Variables } \\
\hline Sex of household head (1 = Male $)$ & + \\
\hline Education of household head $(1=$ Literate, $2=$ Illiterate $)$ & + \\
\hline Religion of household head ( $1=$ Muslim, $2=$ Christian $)$ & - \\
\hline Age of household head (Year) & - \\
\hline Land holding size (Hectare) & + \\
\hline Annual expenditure (Ethiopian Birr) & - \\
\hline Access to credit $(1=$ Yes $)$ & + \\
\hline Access to extension service $(1=$ Yes $)$ & + \\
\hline Total livestock holding (Tropical Livestock Unit) & + \\
\hline Distance from the nearest market (Minute) & - \\
\hline
\end{tabular}


The parameter estimates of multiple linear regressions are merely estimated by ordinary least square method. The presence of multicollinearity among the explanatory variables is checked by the Variance Inflation Factor (VIF) technique. As a rule of thumb, if a VIF of a variable exceeeds10, the variable is said to be highly collinear (Gujarati, 2004). The interpretation of the regression coefficients in a multiple regression is a source of common confusion. The simple regression equation represents a line, while the multiple regression equation represents a plane (in cases of two predictors) or a hyper plane (in cases of more than two predictors). In multiple linear regressions, the constant term $\left(\beta_{0}\right)$ is the value of dependent variable when all explanatory variables are set to zero. The regression coefficients $\left(\beta_{\mathrm{j}}, \mathrm{j}=1,2, \ldots, \mathrm{p}\right)$ can be interpreted as the change in dependent variable to a unit change in respective explanatory variable when the effect of other predictor variables held constant.

\section{Results and Discussion}

\subsection{Descriptive results}

The total sample size handled in the present study was 267 rural households of sinana district. The primary occupation of these households was considered as the main source of their annual income and accordingly classified as involving in government job, trading and farming occupation categories based on the collected information. The result of the study shows that out of the sampled households, $12 \%, 16.5 \%$ and $71.5 \%$ were involved in government job, trading and farming, respectively (Table 2). Majority of the respondents were farmers and they responded that they generate income from non/off-farm activities in addition to farm activities. But, farm activities are the most dominant livelihood base and source of income for the sampled rural households and this result supports the literatures reviewed in section one.

Table 2: Proportion of households by primary occupation

\begin{tabular}{lccc}
\hline Variable & Item & No. of household & Percent \\
\hline Primary & Government job & 32 & 12 \\
occupation & Trading & 44 & 16.5 \\
& Farming & 191 & 71.5 \\
\hline
\end{tabular}

Source: Computed from survey (2017)

Majority of the households were involved in farming occupation category and they generate their income from farming activities while those involved in trading and government job take small proportions. Around $65.8 \%$ of the household heads those involved in farming occupation category were literate which mean at least they can write and read. The analysis of the marital status depicted that the significant proportion of farm households $(81.0 \%)$ were divorced while small proportion (4.8\%) were involved in government job. More than $74 \%$ of the farm households follow Christian religion (Table 3). 
Table 3: Characteristics of households across occupation (Percentage)

\begin{tabular}{llccc}
\hline Variables & Items & $\begin{array}{c}\text { Government job } \\
(\boldsymbol{\%})\end{array}$ & Trading (\%) & $\begin{array}{c}\text { Farming } \\
(\boldsymbol{\%})\end{array}$ \\
\hline Sex & Male & 10.3 & 18.6 & 71.1 \\
\multirow{2}{*}{ Education } & Female & 12.9 & 15.3 & 71.8 \\
\cline { 2 - 5 } status & Illiterate & 2.7 & 17.9 & 79.5 \\
Marital status & Literate & 18.7 & 15.5 & 65.8 \\
\cline { 2 - 5 } & Married & 12.6 & 17.2 & 7.2 \\
& Single & 18.2 & 9.1 & 72.7 \\
& Divorced & 4.8 & 14.3 & 81.0 \\
Religion & Widowed & 10.0 & 15.0 & 75.0 \\
\cline { 2 - 5 } & Christian & 9.9 & 15.8 & 74.3 \\
& Muslim & 13.3 & 16.9 & 69.9 \\
\hline
\end{tabular}

Source: Computed from survey (2017)

The average age of the household heads those involved in farming occupation category was found to be 41.74 years while that of household heads those involved in government job and trading were found to be 32.47 and 38.82 years, respectively. The average family size across the primary occupation was 4.16 for those involved in government job, 4.32 for traders and 5.11 for those involved in farming occupation categories, respectively. Accordingly, the average land holding size, tropical livestock holding (TLU) and market distance for each occupation category can be seen from Table 4.

Table 4: Characteristics of households across occupation (Mean)

\begin{tabular}{lccc}
\hline Variables & $\begin{array}{c}\text { Government job } \\
\text { (Mean) }\end{array}$ & $\begin{array}{c}\text { Trading } \\
\text { (Mean) }\end{array}$ & $\begin{array}{c}\text { Farming } \\
\text { (Mean) }\end{array}$ \\
\cline { 2 - 4 } Age of household head & 32.47 & 38.82 & 41.74 \\
Family size & 4.16 & 4.32 & 5.11 \\
Land holding size & 0.90 & 1.20 & 1.97 \\
Total livestock holding (TLU) & 2.30 & 2.80 & 4.8 \\
Market distance & 41.90 & 38.86 & 42.7 \\
\hline
\end{tabular}

Source: Computed from survey (2017)

Access to credit and access to extension service were other important characteristics of rural households and the study result further depicted that $13 \%, 11.6 \%$ and $75.4 \%$ of the household heads those involved in government job, trading and farming activities have access to credit, respectively. Majority of the farm households (71.5\%) had access to extension service while only $11.4 \%$ and $13.2 \%$ of those household heads who involved in government job and trading, respectively had access to credit (Table 5). It was anticipated that extension service such as formal agricultural training helps farmers to get better production, and then this most likely leads to obtain more income to fulfil their family requirements by enhancing their agricultural production skills, knowledge and experiences. 
Table 5: Proportion of sampled households by accesses to credit and extension

\begin{tabular}{llccc}
\hline $\begin{array}{l}\text { Variables } \\
\text { Item }\end{array}$ & & $\begin{array}{c}\text { Government job } \\
(\boldsymbol{\%})\end{array}$ & $\begin{array}{c}\text { Trading } \\
(\boldsymbol{\%})\end{array}$ & $\begin{array}{c}\text { Farming } \\
(\boldsymbol{\%})\end{array}$ \\
\hline Access to credit & Yes & 13.0 & 11.6 & 75.4 \\
& No & 11.6 & 18.2 & 70.2 \\
\cline { 2 - 5 } Access to extension & Yes & 11.4 & 13.2 & 71.5 \\
service & No & 13.0 & 22.0 & 65.0 \\
\hline
\end{tabular}

Source: Computed from survey (2017)

\subsection{Econometric results}

As highlighted in the methodology section, multiple linear regression was used to explore major determinants of rural households' annual income. The $F$ statistic $(F=23.322)$ as indicated by statistically significant $\mathrm{P}$ - value $(\mathrm{P}=0.000)$ indicates that the model has strong explanatory power. Multicollinearity is the serious problem in some of the econometric models. The value of the variance inflation factor (VIF) ranges from 1.078 to 1.705 (Table 6) confirmed that this problem can be tolerated according to the rule of thumb. In addition to this, square root transformation was applied on dependent variable (annual income) to reduce the variability of annual income of the household heads. Ten variables are entered as explanatory variables in econometric model and four of them were found to be statistically significant. The result $\left(\mathrm{R}^{2}=75.4\right)$ showed that more than $75 \%$ of the square root of annual total income is explained by the significant variables under consideration. The OLS estimation of coefficients of the multiple linear regression model are given in Table 6 and possible discussion and interpretations are as follow.

As hypothesized, age of household head had negative and significant relationship with square root of annual income and the result suggests that for one year increase in the age of household head, there is expected decrease of 0.689 in the square root of annual total income of the households. The result implies that young household heads have greater supply of labour to participate in different activities to generate income than older household heads. According to Amare and Belaineh (2013), older household heads concentrate and devote more of their time on farm operation instead of searching for different income generating sources. The result obtained by the current study is contradictory with that of Yishake and Abebe (2015).

Land holding size became positive and significant determinant of square root of annual total income as per the hypothesis. The parameter estimation of this variable depicts that for one hectare increase in the land holding size, there is 12.264 expected increases in the square root of annual income of households keeping the effect of other variables constant. The implication is that household heads that have large farm land are more likely to diversify the source of income which in turn increases their annual income than those household heads that have small farm size. The result obtained is in line with that of Mekonin (2017). 
Table 6: OLS Estimation of coefficients of multiple linear regression

\begin{tabular}{|c|c|c|c|c|}
\hline Variable & B & S. $\mathbf{E}(\boldsymbol{\beta})$ & $\mathbf{T}$ & VIF \\
\hline Sex of household head $(1=$ Male $)$ & -5.546 & 10.255 & -0.025 & 1.078 \\
\hline Education of hh head ( 1 = Literate $)$ & 10.691 & 10.632 & 1.006 & 1.215 \\
\hline Religion ( 1 = Muslim, $2=$ Christian $)$ & 2.730 & 10.425 & 0.262 & 1.141 \\
\hline Age of household head (Year) & -0.689 & 0.369 & $-1.866 * * *$ & 1.385 \\
\hline Land holding size (Hectare) & 12.264 & 5.454 & $2.248 * *$ & 1.705 \\
\hline Annual expenditure (ETB) & 0.004 & 0.001 & $4.000^{*}$ & 1.318 \\
\hline Access to credit $(1=$ Yes $)$ & 0.673 & 11.311 & 0.059 & 1.089 \\
\hline Access to extension service $(1=$ Yes $)$ & 5.389 & 10.278 & 0.524 & 1.103 \\
\hline Total livestock holding (TLU) & 3.347 & 1.950 & $1.717 * * *$ & 1.634 \\
\hline Distance from nearest market (minute) & -0.160 & 0.128 & -1.247 & 1.107 \\
\hline Constant & 119.48 & 29.06 & 4.112 & \\
\hline \multicolumn{2}{|c|}{ Dependent variable: Sqrt of annual income } & $\mathbf{R}^{2}=75$. & & 0.000 \\
\hline \multicolumn{4}{|c|}{ Significance level: $\quad *(1 \%), \quad * *(5 \%)$ and $* * *(10 \%)$} & $=267$ \\
\hline \multicolumn{5}{|c|}{ F=23.322 $\quad$ TLU $=$ Tropical Livestock Unit $\quad$ ETB $=$ Ethiopian Birr } \\
\hline
\end{tabular}

Source: Computed from survey (2017)

Annual expenditure is found to have positive and significant influence on the square root of annual income. The result further depicted that for one birr increase in annual expenditure, the square root of the annual income is expected to increase by 0.004 keeping the effect of other variables constant. The result obtained here contradicts the hypothesized influence of this variable on the annual total income. This strange result may occur in a case where the households utilized the expenditure on different activities which may accelerate their annual income. For instance, households in farming occupation category can spend part of their annual expenditure on purchase of fertilizers and improved seeds which may increase their outputs. Similarly, traders and government employees can also spend part of their annual expenditure on different activities which can create additional asset so that their annual income may increase.

Tropical livestock holding positively and significantly affected square root of annual total income. Parameter estimation of this variable showed that for one unit increase in TLU, there are 3.347 increases in the square root of annual total income of households keeping the effect of other variables constant. Household heads owning large livestock holding have the capacity to accumulate capital and manage the constraints of cash through participating in different income generating activities when compared to those households with small or no livestock holding. Livestock holding is an important variable proxy for indicating wealth status of the households. 


\section{Conclusion and Recommendations}

As expected, significant number of rural households engaged in agricultural sector in the study area. The result of this study confirmed that large proportion of the sampled household heads $(71.5 \%)$ was involved in farming occupation category which is the main source of their income while small proportion of the household heads was involved in trading $(16.5 \%)$ and government job (12\%), respectively. The result confirmed that farming is the dominant source of income for the rural communities in the study district. The classical linear regression model was used to explore factors influencing annual total income of the sampled households. In order to minimize the variance of annual total income, square root transformation was done and the model results depicted that age of household head, land holding size, annual expenditure and total livestock holding were significant variables influencing square root of annual total income. The value of coefficient of multiple determination showed that more than $75 \%$ of the square root of annual income of the sampled households was determined by these significant variables. The model result further revealed that square root of annual income increases with the increase in land holding size, annual expenditure and total livestock holding in TLU. On the other way, square root of annual income decreases with the increase in age of household head. This shows that young household heads were better off in diversifying their annual income than old household heads. Land holding size of household heads and number of total livestock holding in TLU are among the top important variables to increase the level of annual income in the study area so that they need particular emphasis. Based on the finding of the study, policy recommendations are as follows: Firstly, awareness creation and capacity building for rural households should be strengthen to ensure the diversification of annual income. Secondly, critical emphasis should be given on the land holding management and livestock production so as to diversify cash crops using improved technology to increase the level of annual total income. Thirdly, rural households should be able to exercise other sources of income such as off-farm and non-farm activities to earn better income.

\section{Acknowledgment}

The data used for this study is collected for the study funded by Research, Community Engagement and Technology Transfer Vice President, Madda Walabu University. Special thanks to Mr. Birhane Zelalem for his contribution during data collection.

\section{References}

Aikaeli, J. (2010)," Determinants of rural income in Tanzania". Research on poverty alleviation. An empirical approach, Research report 10/4.

Amare D. and Belaineh L, (2013). Determinants of income diversification among rural households: The case of smallholder farmers in Fedis district, Eastern Hararghe zone, Ethiopia. Journal of Development and Agricultural Economics, http://www.academicjournals.org/JDAE, 5(3): 120-128

Awoniyi, O. and Salman, K. (2008). Non-farm income diversification and welfare status of rural households in South West Zone of Nigeria. 


\section{Macrothink Institute ${ }^{\mathrm{TM}}$}

Bekelu T. and Abdi-Khalil E. (2013). Determinants and Patterns of Income Diversification among Smallholder Farmers in Akaki District, Ethiopia. Journal of Research in Economics and International Finance (JREIF), http://www.interesjournals.org/JREIF, 2(4): 68-78,

Chocran, W. G. (1977). Sampling Techniques, Third edition, Harvard University.

Gujarati, (2004). Basic Econometrics, Fourth Edition: The McGraw-Hill Companies

Haggblade, S., Hazell, P.B.R. and Reardon T. 2007. Transforming the Rural Non-farm Economy, John Hopkins University Press, Baltimore, USA.

International Monetary Fund. (2012), International Jobs Report, Economist Intelligence Unit, Washington, DC.

Mekonin, A.N. (2017). Econometric analysis of determinants of livelihood outcomes of coffee producers in Lalo Assabi district, Ethiopia: Education and Income in focus. Alanya Academic Review Journal, http://dergipark.gov.tr/alanyaakademik, 1(3): 22-36.

National Bank of Ethiopia. (2014/2015). National Bank of Ethiopia annual report

World Bank. (2008). Ethiopia: Climate Factsheet. Draft. Washington DC: World Bank,

Yishake, E. A and Abebe M. S. (2015). Assessing determinants of income diversification among rural farm households in Ethiopia: The case of Leemo and Anileemo districts, Hadiya zone, SNNP. International journal of science and research (IJSR), www.ijsr.net, 5(12):100-110.

Yishak G. (2016). Rural farm households' income diversification,: The case of Wolaita zone, Southern Ethiopia. Internatinal journal of sustainable development research, http://www.sciencepublishinggroup.com/j/ijsdr, 2(2): 6-17

\section{Copyright Disclaimer}

Copyright for this article is retained by the author(s), with first publication rights granted to the journal.

This is an open-access article distributed under the terms and conditions of the Creative Commons Attribution license (http://creativecommons.org/licenses/by/4.0/). 